\title{
Lenart Škof
}

\section{On two Unpleasant Gestures: Rethinking Marion's Critique of Nietzsche and Heidegger in The Idol and Distance}

\section{Dve neprijazni gesti: premislek ob Marionovi kritiki Nietzscheja ter Heideggra v Maliku in razdalji}

Abstract. This paper deals with an analysis of Jean Luc Marion's The Idole and Distance in light of his criticism of Nietzsche and Heidegger. Two unpleasant remarks of Marion are critically confronted and discussed from the point of view of his idea of the distance and idolatry. We argue for a different genealogy of the fatherly distance, one that is more attuned to the original Nietzschean thought and sensitive to the idea of the child. On the other hand, from Marion's criticism of «elemental« ontology of Being in Heidegger we try to argue for another possibility of onto(theo)logy in light of the proximity of the elements and God-Being within the Heideggerian ontological field of Fourfold and Ereignis. In our elaborations, we also invoke contemporary Mormon philosophical theology as an example of a post-Christian thought, being able to address some of the key questions that were haunting Marion in his criticism of both philosophers. From the Fatherly distance in Marion and his charges of idolatry towards various thinkers we thus aim to arrive to the newly coneptualized material and elemental onto(theo)logy of God-Being.

Key words: J.-L. Marion, F. Nietzsche, M. Heidegger, R. Rorty, idol, distance, revelation, Mormonism, materialism.

Povそ̨etek: Članek se ukvarja z analizo Marionovega dela Malik in razdalja v luči njegove kritike Nietzscheja in Heideggra. V njem se kritično odzovemo na dve neprijazni pripombi ter o njima razpravljamo na podlagi Marionove misli o razdalji in malikovalstvu. Prizadevamo si za drugačno genealogijo od tiste, ki vodi v Očetovsko razdaljo, genealogijo, ki je bolj primerna za tematizacijo izvirne Nietzschejeve misli o ideji otroka. Po drugi strani na podlagi Marionove kritike elementarne ontologije pri Heideggru razmišljamo o drugačni možnosti onto(teo)logije - takšni, ki lahko vztraja v luči bližine elementov ter Boga-Biti znotraj heideggerjanskega ontološkega polja četverja ter dogodja. $V$ razpravo kritično vpeljemo sodobno mormonistično filozofsko teologijo, ki kot vzorčni 
primer postkrščanske misli lahko pomaga razrešiti nekatere ključne dileme Marionove misli, ki preganjajo tega filozofa. Iz Očetovske razdalje in iz Marionovih znanih obtožb na temo idolatrije se tako v sklepu premaknemo k na novo utemeljeni materialni in elementarni onto(teo)logiji Boga-Biti.

Ključne besede: J.-L. Marion, F. Nietzsche, M. Heidegger, R. Rorty, malik, razdalja, razodetje, mormonizem, materializem.

This essay ${ }^{1}$ is about some philosophico-theological possibilities, emerging from the unusual but interesting relation between Marion's project in philosophical theology on one hand, and recent liberal philosophico-theological elaborations within Mormonism on the other hand. Many and varied scholars (Davies 2003; Miller 2008; Webb 2013; Givens 2015), have written monographs on Mormonism and its theology. These have received timely critical attention within academic circles, that we argue is deservedly so, and as a consequence they have been firmly placed within the contemporary (post-)Christian thoughts-world. One of the most provocative and original Latter-day Saints theologians, Adam S. Miller, has already put this focus in close conversation with Badiou, Marion and Mormonism (Miller 2008). According to Simon Critchley, as an example of a post-Christian tradition, Mormonism pluralizes divinity and "makes god radically immanent « which enables us to rethink some of the key features of any theology (Critchley 2012). Moreover, with its idiosyncratic theory of matter and related accounts on ontology, cosmology, revelation and eschatology, the Latter-day Saints theology has, in my opinion, become one of the most important and vibrant theological narratives that we have for the 21st century. In this essay we will critically look at two arguments or in my view two disturbing gestures of Marion that I find as perhaps even being key markers of his philosophical intervention into the very core of both phenomenology and theology; on this basis I will critically read Marion's philosophical theology as contrasted to some more recent views on Mormonism. Further, I will also attempt to present (hopefully in a sufficiently humble manner) my own thesis on religion and some of its tasks in today's world.

\section{Marion's Two Unpleasant Gestures}

In his L'Idol et la distance Marion makes two intriguing comments - one on Nietzsche and another on Heidegger - which I wish to take as a starting point of my essay on the relation of theology to ontology, materiality, and salvation. In his analysis of Nietzsche and his "Christology", Marion makes an observation that interests me as an example of an ungentle philosophico-theological reading. In the $\S 6$ he starts with the following sentence:

1 This paper is a result of two research projects The Return of the Religious in Postmodern thought as a Challenge for Theology (J6-7325) and Reanimating Cosmic Justice: Poethics of the Feminine (J6-8265) financed by Slovenian Research Agency (ARRS). 
"The darkness of the final delirium (Wahnsinn) concludes the destruction of idolatrous ilussions (Wahn) by exposing, once the veil is torn, an individual, Friedrich Nietzsche, to the unbearable trial of the divine that is immediately (corporeally) confronted." (Marion 2001, 55)

This observation is followed by another thought in the same section on Nietzsche's Christ, namely, that it was precisely Nietzsche's idolatric confrontation with the divine (in this case only with the "semigod", demi-dieu) that has caused the Nietzsche's final and longlasting fall into the mental illness:

whence the final failure - to which the darkness testified for ten years. /.../ I am saying that the coherence of the Nietzschean text, including the plunge into darkness, becomes visible in this way, in this way more than otherwise, and perhaps that Christ haunts Nietzschean thought more profoundly than as an adversary or a reference - he remains the typical and ultimate place where that thought lives, whether consciously or unconsciously. An empty figure of Christ. " (60f., my emphasis)

Apart from a more ethical point of view of such an etiquette which one could address (for example, why there is a need at all in someone to exert such pressure or an insistence on this issue ad personam), I still wish to reflect on some even more serious philosophical and theological consequences of a such a thought. Clearly, for Marion the Christological gesture of Nietzsche only leads to the semi-death (demi-mort), of Nietzsche's soul/spirit (esprit), but not of his body (corps), which thus tragically or comically (as you wish) survives the necessary breakdown of an allegedly heroic soul of the individual man called Friedrich Nietzsche, and causes his fall into the absyss of unthought. According to Marion, already for Feuerbach it became impossible to evade the idolatrous nature of making his "God" devoid of any remaining feature of negative theology and its inherent distance. Feuerbach and Nietzsche cannot step into the distance and are therefore idolatrous towards their divinities. If Feuerbach was still able to remain at this side of this ontological gap (Kluft), ${ }^{2}$ it was Niezsche who has made one more step and has therefore collapsed into the final transgression, and into the sad and final, but rightly deserved (as it seems if we take Marion seriously enough) entenébrèment of his soul $(1977,104)$.

Is there perhaps another way to think through this aspect of Nietzsche? I wish to argue in favor of Nietzsche by making an unusual step first - namely by invoking the idea of a child as we can find it in his thought. In Thus Spoke Zarathustra Nietzsche famously introduces three metamorphoses of the spirit - namely first the spirit becomes a camel, then the camel becomes a lion, and finally, the lion becomes a child ("On the Three Metamorphoses", Nietzsche 2006, 16). It is decisive, for us, to know that for the play of creation, for Nietzsche, a very special relation to the sacredness is required. The idea of a child is described as follows:

2 See on Feuerbach's philosophy of religion in my Breath of Proximity: Intersubjectivity, Ethics, and Peace (Škof 2015, ch. 5). 
"The child is innocence and forgetting, a newbeginning, a game, a wheel rolling out of itself, a first movement, a sacred yes-saying. Yes, for the game of creation my brothers a sacred yes-saying is required. The spirit wants its will, the one lost to the world now wins its own world. Three metamorphoses of the spirit I named for you: how the spirit became a camel, and the camel a lion, and finally the lion a child. - (17)

In "The Soothsayer", there is another modality, or even acceleration of this thought, when »like thousandfold children's laughter Zarathustra comes into all burial chambers, laughing at these night watchmen and grave guardians, and whoever else rattles about with dingy keys " (108). Here, the idea of a child is even radicalized as representing the only possible way of thinking about the future, since, clearly, the child is the category of the future. But why is the idea of the child so important? Apart from the fact that we do not have any single modern philosopher - with the exception of Nietzsche or Irigaray - that would dedicate an important portion of his or her work to the idea of the child, the most important reason is also that, for Marion, the distance with which we could escape idolatry, can solely be understood and nurtured from the idea of the vertically understood relationality within the very concept of the parenthood: because, as we know from Marion, taken radically, "Paternal distance offers the sole place for a filiation." (Marion 2001, 139)

In To Be Born Luce Irigaray raises the question of the origin as follows: "Unveiling the mystery of our origin is probably the thing that most motivates our quests and plans. " (Irigaray 2017, v) The question of origin can refer to two possible paths: firstly, to the ontological thesis about the origin of our Being, and secondly, but by no means less important, to the question that is most closely connected with the idea of the child. Irigaray introduces her explication of the idea of the child in To Bo Born in an idiosyncratic and, at first, recondite manner: she argues that whatever the factors of our conception or creation as individuals coming to this world, we have wanted to be born - our will to live is manifesting itself already at the moment of our birth. (1) In this gesture she allies herself to this aspect of Nietzschean thinking, and this, naturally, leads to a break with the established perception of the child as the third one in relation to its parents, or, as is the case with Marion, as the second to his father (filiation) - as the one who is born and thus does not give birth to oneself, and, consequently, does not have his own self-affection (including the debates around filioque). But if the original idea of the child is related to its explicit singularity (which assures the child its autonomy) another ontology of the child is needed. Based on this, I wish to argue that between parents and children, even when being fully devoted to their child (or to each other), this relationship essentially and ontologically is not hierarchical, as their complete and unconditional love is fed precisely by what they themselves and each on their own had never possessed or been and by what they in equal perfection receive from their child, or from their parent; this is what vertical transcendence of the relationship and exchange of love consists in - it is a 
process of reciprocal giving and thus of the gift of mutual love among them all (this love being the third thing now). Now, to bring these thoughts back to my previous Nietzsche-Marion dispute: if filiation is only possible through the onto-theological gap (distance), then the very idea of a child, as described above, and ontologically, evaporates into nothingness and indeed becomes an empty figure, if we may use Marion's own terms here. One more time, according to Marion, now with the passage in its entirety:

»Paternal distance offers the sole place for a filiation. Since in the intimacy of the divine strictly coincides with withdrawal, the paradox can lead to confusion: distance must, in order that we might inhabit it, be idenfitied. We will be able to speak of it only if we come from it and remain in it. To speak of distance: concerning it, and also starting from it. But which language can be suitable to distance? « (Marion 2001, 139)

We have now come full circle: but a further step needs to be taken - from distance to proximity, and from ontological gap to material closeness of a processual divine-human relationship, which will be a topic of the next part of this paper.

Let me now focus on the second ungenerous comment by Marion from The Idole and Distance, this time on Heidegger's ontology. Towards the end of The Idole and Distance, Marion critically elaborates on the possibility of Christians positioning themselves within the Ereignis. For Marion, after dealing with Derrida's différance and trace there is a nihilism at work, when there is nothing that could be invoked, called - all there is, is the "platitute of différance, since the trace removes any name for it, disqualifies any identification of it, and finally fills any of its depth« (225). Derrida, in this »abyssal thought« (225), is in fact not far away from Nietzsche, for Marion. All is indifferent, there is no transcendence, and beyond ontotheology (including the ontological difference itself) the Being of being is indifferently differentiated into the nothingness. The distance of the Father, clearly, cannot be present or encapsulated in this process. Marion knows that in order

"To eliminate any paternal site, it is necessary to reject the ontological difference. /.../ The refusal of ontological difference in the one case, and its assertion in the other, aim at the same goal: to reduce to the Neuter, to neutralize the distant irruption of the Father.« (231)

In this sense there is another, this time final possibility that now has to be taken into consideration: it is Heidegger's Ereignis and the posibillity of an ontological difference/distance. The entire $\S 19$ (titled »The Fourth Dimension «) of The Idole and Distance deals with that possibility. Heidegger's lecture »Time and Being " is now crucial for Marion since it introduces the notion of giving. For Heidegger, Being as giving is presented as follows:

»What determines both, time and Being, in their own, that is, in their belonging together, we shall call: Ereignis, the event of Appropriation. Erei- 
gnis will be translated as Appropriation or event of Appropriation. One should bear in mind, however, that sevent is not simply an occurrence, but that which makes any occurrence possible. /.../ However: Appropriation neither is, nor is Appropriation there. (Heidegger 1972, 6; 8; 19)

But, from these still more abstract thoughts on Being as Ereignis, we can say that Heidegger's event of appropriation is also necessarily related to the gentle constellation of the selements " of being, and thus related to the discrete or hidden, but still discernable »material« ontology of Being. Heidegger's proximity to the elemental world is, for example, visible in the Introduction to his essay "What is Metaphysics?", when the earth/soil is presented as a root of the nourishing sources and strenghts or the tree $(2007,277)$. But it is in Building Dwelling Thinking that he elaborates on the elements in the following way:

"Earth is the serving bearer, blossoming and fruiting, spreading out in rock and water, rising up into plant and animal. When we say earth, we are already thinking of the other three along with it, but we give no thought to the simple oneness of the four. /.../The sky is the vaulting path of the sun, the course of the changing moon, the wandering glitter of the stars, the year's seasons and their changes, the light and dusk of day, the gloom and glow of night, the clemency and inclemency of the weather, the drifting clouds and blue depth of the ether." (1971, 147-148)

We have earth/rock, plants and animals, water, the atmosphere (with winds, air or ether), and sun/light/fire in Heidegger. All these archaic elements in their mysterious but visible materiality in the midst of the Fourfold are the source or our All-life and our being/Being. But in an even more elemental sense, and in a complete syncronicity with the inner dynamics of the Fourfold, for Heidegger there is one of the elements that still is privileged, and this is precisely the wind/air/ ether - or, with the words of Heidegger: "Beyng is the ether, which man breathes" $(2014,231)$. Appropriation appropriates, but the distance within the ontological difference can neither be called »idolatrous « nor can it be dispossesed of its ontological meaning here. It is rather "spiritual « - but in a subtle material way. Now, to return back to Marion - based on these thoughts, in his critical exposition of Heidegger, our philosopher is able to guide us towards the conclusion, namely, that in the context of "Time and Being", neither time nor Being exist. The I/ y $a$ of a Being (Es Gibt: as an impersonal Es which gives itself) is Ereignis (the event of Appropriation). Ereignis and distance are now incomensurable, since it is Ereignis itself which posits into the distance from the distance itself, for Marion (Marion 2001, 239ff.). Now, another dimension - the so called the fourth dimension - reveals from this constellation when we talk about the difference between God and Being, and this is the Distance itself:

"The fourth difference, between God and Being, puts the other differences in place, because to begin with it gives rise to the (unextended, nonspatial) space where these differences, including the ontological difference, 
become imaginable. The fourth dimension, the last, is always the first. It is a question in fact of distance itself, such as it passes beyond every possible idol, and exercises itself as the distance of Goodness. " (246)

Ereignis could under certain conditions even support this fourth dimension, but we are now coming to the very core of Marion's criticism of Heidegger: the play of Ereignis cannot, and this is now clear and undisputable, satisfy Christians in their radical ontological standing towards Being: not only being as such, but Being »itself « is now logically put into radical suspension, evaporation, the fall into nihilism. Here we are now at our second ungentle remark, or gesture of Marion, that I wanted to analyse. On the basis of previous criticism of Ereignis, Marion writes again a very unpleasant or disturbing observation, which is now also very straightforwardly elucidated with the following words:

»From the point of the view of charity, everything enters into another light: Beings and Being itself appear, certainly not annihilated of without value (for nihil and value come to us from metaphysics), but nil in charity, inept because inapt for distance, in a word, vain. Vain, in the sense that svanity of vanities, all is vanity must be understood more or less as: Iwind, nothing that holds, nothing but windk. That which reveals itself at this point to be vain (vergeblich) - namely, Being as well as beings - departs like wind. But the swind indicates also the spirit, which sbreathesı. Can the inanity of Dasein, like swind, offer a name to the Spirit, offer its inanity (Vergeblichkeit) and give it (geben) to another authority? /.../ The ontico-ontological inanity uncovers such a poverty to charity (distance), that charity cannot but remit it to it /.../ [B] ut only a forgiveness can grant it that one not impute that absence to it as a fault. /.../ Only forgiveness will allow us to receive it [namely, Being, L.Š.] as a gift without abandoning ourselves to its serene inanity. /.../ For what places Being in distance as an icon of distance remains first the humble and unthinkable authority of the Father.« $(252 ; 253)$

Here Marion uses the play of words, in which "wind " is particularly exposed as a symbol of ontological nihilism. We know that wind (and breath as its microcosmic twin) has had an imporatant role in the cosmologico-ontological constellation of Being since the Presocratics, although it has later been supressed or forgotten (see for example Irigaray's The Forgetting of Air in Martin Heidegger ${ }^{3}$ ). Secondly, Marion thinks about the possibility of Dasein (cynically, though) as an existence to interfere with the plane of grace, but even if so, without any trace of joy. Here we come close to Nietzsche: for Nietzsche, we have seen, it is in the child and its laughter (and joy) that a new beginning is possible - thinking beyond nihilism, beyond metaphysics, beyond idolatry. It seems that Marion would like to warn us against making this essentially dangerous step into laughter and joy of

3 More on this in my Breath of Proximity (Škof 2015) which is entirely dedicated to this forgotten but sacred element. 
life: with his first remark on Nietzsche, the idea of a child has evaporated into nothingness and became an emtpy figure. With the second gesture which Marion makes against Heidegger, Being or Event of Appropriation (Ereignis) is cut off from any remains of even the most discrete presence of material signifiers. But this only means that, based on the thought of Being as an icon of distance, Marion itself establishes and insists on the idolatrous distance of the Father of Being which, in my opinion, needs to be deconstructed in favor of a more gentle, intimate, and elemental gesture of divinity, or God-Being, that both has a body and indwells in an ontological proximity which still needs to be philosophically explained and theologically revealed.

\section{Against idol and distance - on the plan of salvation in Mormonism and its philosophical theology of matter}

Let me first briefly present some basics of Mormon Christianity. For the Later Day Saints, the idea of God cannot be related to the metapyhsical triade of incorporeus, impartibilis and impassibilis. For Joseph Smith, not only Jesus, but also God the Father is passible, and weeps with us. The portrayal of a weeping God is directly opposed to ideas of the early Greek fathers which persisted through the history of Christianity until the modern era - namely that God (the Father) cannot be changed or affected by emotions (Givens 2015, 85ff.). Distant God without the body or (bodily) parts, and God that is unchangeable, cannot really be vulnerable to external events and thus also cannot be affected by any possible external perturbations. But if we allow ourselves to think of God as vulnerable and thus changeable, this diminishes the distance between God and us and opens immense possibilities for a theological revitalization of the divine-human relationality, with all ethico-eschatological consequences of such a turn. If God weeps, and if weeping means that God's (not "only" Jesus') tears are then "real« and necessary, God must also have had a material substance that we cannot yet comprehend. Spirit and element - i.e., God and his/her tears are not separated any more, in the words from Doctrine and Covenants - "spirit and element, inseparably connected, receive a fullness of joy; And when separated, man cannot receive a fullness of joy (D\&C 93: 33-34). ${ }^{4}$ On this basis we must contend that within Mormon cosmology (and theology), there is a radical counter-movement as regards the realms of spirit and matter. According to one of the most prolific Mormon thinkers

4 The Mormon scriptures (four primary texts, also called Standard Works), consist of: The Bible (KJV), Book of Mormon (1830), Doctrine and Covenants (1835; D\&C), and Pearl of the Great Price (1851). If not otherwise indicated, the citations from the scriptures are from the official LDS Church website at https://history.lds.org/article/web-resources?lang=eng. This citation from D\&C goes as follows:

32 And every man whose spirit receiveth not the light is under condemnation.

33 For man is spirit. The elements are eternal, and spirit and element, inseparably connected, receive a fulness of joy;

34 And when separated, man cannot receive a fulness of joy.

35 The elements are the tabernacle of God; yea, man is the tabernacle of God, even temples; and whatsoever temple is deified, God shall destroy that temple. 
John Durham Peters, Mormon cosmology »is the story of humankind's increasing immersion in matter for the sake of progress and growth (Durham Peters 1993, 47). This means that in the process of our spiritual growth, both realms - of spirit and matter - commingle and in this sense also Heavens are only the exaltation of this world, for Mormons (this is also one of the features that Rorty praised most in Mormonism which obviously was close to his romantic "faith « in the human progression). In the Doctrine and Covenants we also read that "God the Father and his Son have tangible bodies of flesh and bone " (Durham Peters 1993, 47; see D\&C $130,22^{5}$ ), and for the leading early Mormon theologian Orson Pratt, any theology that was not willing to deal with this kind of theological materialism seriously enough, was no less than absurd.

Now, for the sake of a better understanding of this context, a short review of Mormon theology is needed. Mormon theology distinguishes radically from other Christian trinitarian doctrines in its teaching that there are God, the Eternal Father (and, sometimes, also Mother), His Son, Jesus Christ, and the Holy Ghost, but with an important difference, namely, that Jesus is identified with Jehovah (according to the teachings of Joseph Smith, Jesus Christ only became divine at some point »in the distant pre-earth past"; Givens 2015, 122). God the Father (and, sometimes Mother) is now identified with Elohim in its original plural meaning, and thus representing the "Gods" in their plurality rather than being one and only God (Davies 2003, 68). If both God the Father and Son have tangible bodies, finally, the Holy Ghost is more purely spiritual although still enigmatically subtely material in its ontological character. Although some Mormons think that it also must possess a certain kind of a spiritual bodily substance, it usually will be recognized in the form of an unembodied cosmic ether, being able to »dwell in us " (D\&C, $130,22)$. This is interesting since it relates to the remark of Marion on the vanity of wind as related to the onto-theological concepts of Being and God. Furthermore, for Mormonism, God is supreme intelligence, but whe is not the source of all being, or even the creator of that which constitutes the human soul. Men and women have existed from eternity as uncreated intelligence." (Givens 2015, 45). How could this be understood? For Mormonism, creatio ex nihilo is therefore not an option and this clearly paves the way towards another theory of an independent and eternalist matter and element within the theology. In this light, embodiment, which usually was understood theologically as a degradation of the pure spiritual existence into the material form, is now rather a step upward. Since God (which comprises both heavently Father and Mother ${ }^{6}$ ) is itself embodied, this is the reason that men and women themselves can expand toward divinity to par-

5 Full citation from D\&C 130, 22: "The Father has a body of flesh and bones as tangible as man's; the Son also; but the Holy Ghost has not a body of flesh and bones, but is a personage of Spirit. Were it not so, the Holy Ghost could not dwell in us."

6 See on this teachings about Mother in Heaven by various Mormon theologians and thinkers. Since 1854 revelation of Sister Eliza R. Snow about Mother in Heaven in »O My Father « hymn, this topic developed into an (un)official doctrine of the LDS. On this, and related dogmatic controversies over the decades see Paulsen and Pulido (2011) and Taylor G. Petrey's »Rethinking Mormonism's Heavenly Mother" (2016). 
ticipate more and more in an ongoing process of salvation in which God desires to save the entire humankind. As man is, God once was, as God is, man may become. In this view cosmos is essentially ontologically continuous, and the fatherly distance evaporates into the teaching on God's progression and passibility:

"Mormon rejection of creation ex nihilo in favor of creation ex materia, out of preexisting intelligence and element, together with the corollary that matter is uncreated and coeternal with God, affirm that the primordial origin of being is plural, not singular. Irreducible plurality is the fundamental character of being. The Mormon teaching that the spirit world is coextensive with the physical world suggests the immanence of the divine and orients the theological imagination toward the here and now rather than toward the transcendent." (Welch 2017, 69)

I now wish to address the second topic of my investigation - namely to elaborate on this basis on Marion's second remark on the vanity of wind and related question of Being. In perhaps the most important of the sermons of Joseph Smith now known as The King Follet Discourse (from 1844) - we find the clearest distillation of Mormonism's more radical views, but before that what strikes us is a remark that he makes in the very beginning of this sermon. ${ }^{7}$ The subject of the sermon is the death of King Follett, a fellow Mormon who died in March 1844, only few months before the prophet itself has died. Joseph Smith starts his speech with a prayer - namely by seeking the inspiration (here in the most literary sense - as being filled with pneuma) in the Holy Spirit and by wishing "that the Lord may strenghten my lungs and stay the winds (Smith 1844; »lungs " are here being used as a bodily-spiritual $\operatorname{organ}^{8}$ ). In this sermon, Smith first contends that God himself "is a man like one of you «, which dwellt on the earth as Jesus did. ${ }^{9}$ Now, according to Smith, also a God had to become God, actually, all Gods have done this before (remember the plurality of Gods as a principle in Mormonism). Now, a crucial argument appears: since creatio ex nihilo is not possible, God had before him materials. i.e., the elements, from which he organized (and hence not created) the world. These elements had their existence from the time they had - they are coeternal with God, and even more: "The pure principles of element are principles that can never be destroyed; they may be organized and reorganized but not destroyed." (Smith 1844) And in Doctrine and Covenants we also read:

"There is no such thing as immaterial matter. All spirit is matter, but it is

7 The King Follet Discourse is regarded by many as Joseph Smith's greatest sermon. It was delivered in front of a large audience (estimated at 8.000) on April 7, 1844 (few month before his death). On that day, Smith spoke for more than 2 hours and three men made official notes, and by adding the fourth source, and with comparing of various versions, the sermon was completed and composed in the current version. On this and more details on the historical setting of the sermon see Cannon (1978).

8 See on the ethical relevance of »lungs in Levinas's thought in my Breath of Proximity (Škof 2015, 137).

9 All citations from The King Follet Discourse, if not otherwise indicated, are from the official online version, available at: http://mldb.byu.edu/follett.htm (Smith 1844). For more on these radical aspects of thinking about the progression of God(s) and divinizing of the humanity see Critchley 2012. 
more fine and pure, and can only be discerned by purer eyes. We cannot see it; but when our bodies are purified we shall see that it is all matter." (D\&C 131,7-8)

Mormons therefore establish the realm of the elements (or matter) as a primordial ontological plane from which all beings have once emerged. ${ }^{10}$ But why is the role of the air or wind as an element so special in this constellation? And why did Marion choose precisely wind and rather not some other element - for arguing against Heidegger's Being?

We have already seen that for Heidegger, wind had rather a key role within the ontology of Being/Beyng (if we remember his remark on Beyng as ether): now, in his reading of Hölderlin's Hyperion, Heidegger even thinks about the air that is breathed by all living beings, as: ") This air hallows the holy air, sister of the spirit, mighty master of the fire which reigns and lives within us" (Heidegger 2000, $\left.109^{11}\right)$. This is a proof that, even for Heidegger, spirit was elementarily linked to its archaic and subtle material core. These observations do not correspond to Marion's remark and show that he is among those philosophers that unfortunately are not sensible to the respiratory aspects of our being. ${ }^{12} \mathrm{Now}$, also for Smith the inspiration of the Holy Spirit is crucial and among the sins committed, according to The King Follett Discourse, there is only one that cannot be forgiven - and it is the sin against the Holy Ghost. ${ }^{13}$ The respiratory thinker Petri Berndtson has already shown the importance of the relation between God and spirit/breath/air/ wind (as pneuma) - as in John 4:24, where Jesus answers to Nicodemus' question about the new birth with the following words:

„Very truly, I tell you, no one can enter the kingdom of God without being born of water and Spirit [ex hydatos kai pneumatos] /.../ The wind blows where it chooses, and you hear the sound of it, but you do not know where it comes from or where it goes to. « $(\mathrm{Jn} 3: 5,8)$

Based on these thoughts, interpreted in a horizontal and elemental $» r e s p i r a-$ tory" (pneuma) and not vertical and metaphysical »spiritual " (spiritus) manner, Berndtson (2013) argues that The Bible should be reread and reintepreted in an elemental sense - as a text being much more closely connected to the original or archaic elemental constellation. But we must return to Marion now for one more time: for him, there is a double movement in wind - firstly, it shows itself in its sheer vanity or nothingness, it evaporates before Being is reached, or, Being itself evaporates with(in) it. Secondly, and despite that, wind could perhaps still lead us towards the spiritual and thus it could »offer a name to the Spirit« (Marion 2001,

10 See here excellent interpretation of Mormon theology and materialism in ch. "What's Up with Mormons and Matter« (Webb (2013).

11 The part of the sentence that is from Hölderlin, is from Hyperion, Part 1, Book 2, II, 147.

12 For more on problems related to respiratory thinking see Atmospheres of Breathing, ed. by L. Škof and P. Berndtson (2018).

13 Mormons usually refer to Holy Ghost rather then to Holy Spirit although both designations are used. 
252) - but this could only happen in a way of giving up its "material « essence to the elevated and distanced authority of the Father and this is yet another dead-end for the element of the wind.

In his more recent thought on saturated phenomena (see Giveness and Revelation - i.e. his 2014 Gifford lectures), Marion represents the unity and continuity of his thinking over the decades by adding important new elements - which are known as saturated phenomena. Revelation now »encompasses the four types of saturated phenomena (the event, the idol, the flesh, and the icon; Marion 2016, viii), and Jesus Chirst itself is a saturated phenomenon and "the Icon of the invisible God" (ix). We must ask ourselves whether this new constellation could perhaps offer us an alternative way of thinking with or through the elemental plane. The Holy Spirit, as the third person of the Trinity, is now revealed to us as the giveness of the gift, donum Dei. His $\left(\operatorname{sic}^{14}\right)$ role is that "the Holy Spirit enables the paternal depth of the filial icon to be seen, which no one can see without him and outside of him « (114). Finally, no revelation is possible without the inherent paradox that must be accepted as such: No one has ever seen God, because he remains "the only God, invisible" dwelling »in unapproachable light, and whom one among men can ever see" (hon oudeis anthrōpōn oude idein dynatai) (1 Tm 6.16), and of whom sthe only Son, who is turned toward the Father's bosom, has made the exegesis (eikenos ezègēsato) « (Jn 1:18), under the pre-eminently paradoxical title of sicon of the invisible God (eikōn tou theou tou aoratou) (Col. 1:15; see 2 Cor 4:4).

It seems, then, that even in his most recent thinking, Marion is still not willing to let distance of the Father to give its way to a more elemental ontological understanding. Or, in Marion's own words: "No misinterpretation of Revelation could surpass that of Heidegger /.../ who wanted to submit the Revelation of God to the manifestation of the gods, that manifestation to the dwelling of the divine, that dwelling to the opening of the sacred, and that opening to the intact open region of Being." (Marion 2016, 57)

The icon of distance that has never allowed us to breathe the air of proximity.

\section{Conclusion}

I have already argued that, in my opinion, Marion insists on the idolatrous distance of the Father of Being which rather needs to be deconstructed in favor of a more gentle and intimate gesture of divinity, a God-Being, as it were, that both indwells in a bodily and spiritual manner as well as in an ontological proximity to

14 One cannot stop wondering about this insensitivity for sexual difference in Marion, and similarly, in the major philosophical traditions of Western thinkers (with some rare exceptions, such as Feuerbach in the 19th century, and among more contemporary philosophers Derrida and Badiou, and, of course, Beauvoir and Irigaray. See also Hawke (2018) who, taking her lead from Irigaray, does consider this insensitivity in the way cosmic worlds have been written up without acknowledgement of the »theological exile« (42) of female deities, sexual difference and an »ontology of maternal asylum« (44). 
all of "us" (the elements, plants, nonhuman animals, human beings, divine beings) which still needs to be philosophically explained and theologically revealed in future post-Christian theology. In one of the most generous and thorough accounts on Mormonism and interfaith dialogue, Mormon Christianity, Stephen Webb presents us with a beautiful and theologically sensitive correction of any claim that God even could not have a being. (Webb 2013, 29) According to the Mormon belief, God is not "radically different from everything else that exists" (33) but this does not imply any simplistic or materialistic theory, underpinning such a statement. Finally - and thus to wind up this essay - thinking beyond any materialism-immaterialism divide, "God is mysterious but not indescribable, glorious but not unknowable, perfect but not infinite and unlimited « (37).

\section{References}

Berndtson, Petri. 2013. The Temple of the Holy Breath as the Place of Conspiracy between the Respiratory Body and the Space of Open Air. In: Art and Common Space, 39-47. Edited by Anne-Karin Furunes, Simon Harvey and Maaretta Jaukkuri. Trondheim: NTNU.

Cannon, Donald Q. 1978. „The King Follet Discourse: Joseph Smith's Greatest Sermon in Historical Perspective«. BYU Studies 18, no. 2:1-14.

Critchley, Simon. 2012. Why I Love Mormonism. The New York Times, September 16. https:// opinionator.blogs.nytimes.com/2012/09/16/ why-i-love-mormonism (accessed April 20, 2019).

Davies, Douglas J. 2003. An Introduction to Mormonism. Cambridge, UK: Cambridge University Press.

Derrida, Jacques. 2009. Writing and Difference. Tr. Alan Bass. London and New York: Routledge.

Doctrine and Convenants. S.a. Available at: https://history.lds.org/article/web-resources?lang=eng.

Feuerbach, Ludwig. 1957. The Essence of Christianity. Tr. G. Eliot. New York: Harper.

Hawke, Shé M. 2018. The Exile of Greek Metis: Recovering a Maternal Divine Ontology. In: Ontologies of Asylum. Ed. by L. Škof and B. Gornik. Poligrafi 23, no. 91/92:41-75.

Holy Bible. 1989. The New Revised Standard Version. Nashville: Thomas Nelson Publishers.

Horner, Robyn. 2005. Jean-Luc Marion: A Theo-logical Introduction. Aldershot, UK and Burlington, USA: Ashgate.

Givens, Terryl L. 2015. Wrestling the Angel. Oxford: Oxford University Press.

Heidegger, Martin. 1971. Poetry, language, thought. Tr. A. Hofstadter. New York: Harper and Row.
- - . 1972. On Time and Being. Tr. by Joan Stambaugh. New York: Harper \& Row.

- - . 2000. Elucidations of Hölderlin's poetry. Tr. K. Hoeller. New York: Humanity Books.

- - . 2007. Pathmarks. Ed. W. McNeill. Cambridge: Cambridge University Press.

- - - 2014. Überlegungen II-VI: Schwarze Hefte 1931-1938. GA 94. Ed. P. Trawny. Frankfurt am Main: Klostermann.

Irigaray, Luce. 1999. The Forgetting of Air in Martin Heidegger. Tr. by Mary Beth Mader. Austin: University of Texas Press.

- - . 2017. To Be Born. Palgrave Macmillan.

Marion, Jean-Luc. 1991. God Without Being: Hors Texte. Trans. Thomas A. Carlson. Chicago and London: The University of Chicago Press.

- - . 2001. The Idole and Distance: Five Studies. Tr. by Thomas A. Carlson. New York: Fordham University Press.

---. 2016. Giveness and Revelation. Trans. Stephen E. Levis. Oxford: Oxford University Press.

Miller, Adam S. 2008. Badiou, Marion and St Paul: Immanent Grace. London: Bloomsbury.

- - - 2016. Future Mormon: Essays in Mormon Theology. Salt Lake City: Greg Kofford Books.

Nietzsche, Friedrich. 2006. Thus Spoke Zarathustra. Eds. A. Del Caro and R. Pippin. Trans. Del Caro. Cambridge, UK: Cambridge University Press. https://doi.org/10.1017/ cbo9780511812095

Paulsen, David L., and Martin Pulido. 2011. „A Mother There «: A Survey of Historical Teachings about Mother in Heaven. BYU Studies 50, no. 1:71-97.

Peters, John Durham. 1993. Reflections on Mormon Materialism. Sunstone, March, 47-52. 
- - . 2015. Marvelous Clouds: Toward a Philosophy of Elemental Media. Chicago: University of Chicago Press.

Petrey, Taylor G. 2016. Rethinking Mormonism's Heavenly Mother. Harvard Theological Review 109, no. 3, 315-341. https://doi.org/10.1017/ cbo9780511812095

Smith Joseph. 1844. The King Follett Discourse. Times and Seasons, 5: 612-617. http://mldb. byu.edu/follett.htm (accessed April 20, 2019).

Škof, Lenart. 2015. Breath of Proximity: Intersubjectivity, Ethics, and Peace. Dordrecht: Springer.
Škof, Lenart, and Petri Berndtson, eds. 2018. Atmospheres of Breathing. New York: SUNY Press.

Webb, Stephen H. 2013. Mormon Christianity. Oxford: Oxford University Press.

Welch, Rosalynde. 2017. The New Mormon Theology of Matter. Mormon Studies Review 4, no. 1:64-79. https://doi.org/10.18809/ msr.2017.0105 